\title{
ZONA HIDROLISIS DAN PERTUMBUHAN BAKTERI PROTEOLITIK DARI SEDIMEN EKOSISTEM MANGROVE Rhizophora mucronata TELUKAWUR - JEPARA
}

\author{
Muhammad Zainuddin ${ }^{1}$, Wilis Ari Setyati ${ }^{2}$ dan Person Pesona Renta ${ }^{3}$ \\ ${ }^{1}$ Program Studi Budidaya Perairan, Universitas Islam Nahdlatul Ulama, Jepara. \\ ${ }^{2}$ Departemen Ilmu Kelautan, Universitas Diponegoro, Semarang. \\ ${ }^{3}$ Program Studi Ilmu Kelautan, Universitas Bengkulu, Bengkulu. \\ Email : zain_mz86@yahoo.com
}

\begin{abstract}
Abstrak
Pemberian pakan dalam sistem budidaya udang berpotensi terjadi pencemaran internal. Oleh sebab itu, penelitian ini bertujuan untuk isolasi, seleksi dan kajian pertumbuhan bakteri proteolitik dari sedimen ekosistem mangrove Rhizophora mucronata Telikawur - Jepara sebagai kandidat water probiotik untuk membersihkan limbah internal. Penelitian ini dilakukan dengan menggunakan metode eksperimen laboratoris di Laboratorium Prodi Budidaya Perairan UNISNU - Jepara. Hasil pengamatan data TPC menunjukkan bahwa kelimpahan bakteri sebesar 282 × $103 \mathrm{cfu} / \mathrm{ml}$. Berdasarkan data purifikasi, didapatkan sebanyak 46 isolat. Data uji proteolitik kualitatin menunjukkan terdapat $89 \%$ isolat tidak aktif, sedangkan $11 \%$ (5 isolat TA.R.14, 16, 22, 31 dan 39) memiliki aktivitas proteolitik. Kelima isolat memiliki ratio hidrolisis berbeda secara signifikan (p < 0,05) secara berurutan sebesar 1,27a; 1,96d; 154b; 169bc dan 1,71c. Aktivitas proteolitik tertinggi pada isolat TA.R.16 memiliki puncak tertumbuhan pada hari ke 30 dengan nilai kepadatan $18,649 \pm 0,789^{\mathrm{h}} \mathrm{sel} / \mathrm{ml}$, stasioner pada jam ke $30-36$, dan mengalami kematian pada jam ke-42. Nilai jumlah generasi sebesar 5,213 $\pm 0,281$; waktu generasi sebesar 5,766 $\pm 0,303$ jam dan laju pertumbuhan sebesar $0,120 \pm 0,006$ jam- 1 .
\end{abstract}

Kata kunci : sedimen, mangrove, bakteri, proteolitik, pertumbuhan.

\section{PENDAHULUAN}

Dalam budidaya udang, sekitar $60-70 \%$ dari total produksi merupakan pengeluaran untuk pengadaan pakan. Evisiensi pakan yang diberikan pada proses budidaya udang sangat kecil yaitu hanya sekitar $22 \%$ dikonversi menjadi pertumbuhan, sedangkan sebesar $78 \%$ adalah pakan yang tidak dimakan atau tidak terserap oleh tubuh. Sisa pakan tersebut akan terakumulasi menjadi limbah organik yang dapat menurunkan daya dukung lingkungan diantaranya memacu pertumbuhan mikroorganisme patogen (penyakit) dan memacu proses dekomposisi anaerob yang bersifat toksik, mengganggu fisiologi, metabolisme dan menghambat pertumbuhan udang vannamei (Hsu and Chen, 2007).

Menurut Setyati et al., (2014) limbah orgnik yang terakumulasi di dasar sedimen merupakan permasalahan yang harus diselesaikan. Salah satu penyelesaian yang efektif adalah melalui aplikasi bakteri water probiotik. Water probiotik adalah bakteri konsorsim yang saling mendukung satu sama lain dalam melakukan bioremidiasi limbah organik. Bioremidiasi adalah pemanfaatan agen mikrobiologi untuk melakukan pembersihan atau penguraian limbah bahan organik. Berdasarkan komposisi pakan, protein memiliki kandungan tertinggi yaitu sebesar $25-35 \%$, sehingga kandungan limbah organik terbesar adalah protein. Oleh sebab itu, konsorsium water probiotik mengutamakan keberadaan bakteri proteolitik. Bakteri proteolitik adalah bakteri yang menghasilkan enzim ekstraseluler protease untuk menghidrolisis protein menjadi asam amino. Berdasarkan uraian diatas maka penelitian ini melakukan pencarian bakteri proteolitik yang dapat digunakan sebagai kandidat konsorsium water probiotik. Salah satu lokasi yang potensial terdapat bakteri proteolitik adalah dari ekosistem mangrove.

\section{METODE PENELITIAN}

\section{Waktu dan Tempat}

Materi penelitian ini adalah sedimen mangrove diambil di lokasi sampling ekosistem mangrove Rhizophora mucronata daerah Telukawur Jepara. Sampel sedimen ekosistem mangrove $\mathrm{R}$ mucronata diambil pada permukaan sedimen hingga kedalaman $10 \mathrm{~cm}$.

\section{Metode Penelitian.}

Penelitian terdiri dari 4 tahap yaitu : (1). Isolasi menggunakan metode pour plate dan perhitungan TPC bakteri menggunakan metode hitungan cawan (Waluyo, 2007). (2). identifikasi morfologi koloni (tipe bentuk, tepian, warna, tekstur) dan purifikasi bakteri menggunakan metode streek plate, (3). uji aktivitas proteolitik secara kualitatif menggunakan metode doting, sedangkan uji secara kuantitatif menggunakan metode divusi agar (Bairagi 
et al., 2002). (4). Kinetika pertumbuhan bakteri menggunakan parameter pertumbuhan OD dan berat kering sel.

\section{Isolasi Bakteri}

Sampel sedimen diambil 5 gram dan dimasukkan ke dalam tabung reaksi yang berisi $5 \mathrm{ml}$ air laut steril, divortex hingga homogen sehingga diperoleh pengenceran 100 . Selanjutnya dari pengenceran 10-0 diambil dan dilakukan pengenceran bertingkat hingga 10-5 (Taslihan, et al, 2001). Masing-masing pengenceran dilakukan penanaman menggunakan metode pour plate. Sebanyak $100 \mu$ l sampel pengenceran di masukkan ke dalam cawan petri steril dan selanjutnya dituang media Zobell agar sebanyak $\pm 15 \mathrm{ml}$, di homogenkan dan di inkubasi selama 24 jam pada suhu pada suhu ruang (Setyati et al., 2014).

\section{Perhitungan Jumlah Koloni (TPC)}

Perhitungan jumlah koloni menurut Waluyo (2008), metode hitungan cawan di dasarkan pada anggapan bahwa setiap sel dapat hidup dan berkembang menjadi koloni yaitu koloni yang tidak terkontaminasi dan tidak terbentuk swam. Tingkat pengenceran yang digunakan dalam perhitungan adalah yang memiliki jumlah koloni antara 30-300 koloni.

\section{Identifikasi Morfologi Koloni Dan Purifikasi}

Hasil isolasi bakteri dilakukan identifikasi morfologi koloni dan purifikasi. Identifikasi morfologi koloni terdiri dari warna, tepian, bentuk, dan tekstur (Irianto 2006). Morfologi koloni dipisahkan dan dimurnikan dengan metode goresan (Taslihan et al, 2001). Isolat murni selanjutnya disimpan dalam agar miring dengan ditambahkan campuran gliserol-skim milk kemudian disimpan pada suhu $-80 \mathrm{oC}$.

\section{Uji Aktivitas Proteolitik}

Uji kemampuan isolat bakteri menghasilkan enzim proteolitik dilakukan menggunakan uji kualitatif dan kuantitatif. Uji kualitatif dengan cara mengambil isolat hasil pemurnian pada media miring sebanyak 1 ose inokulasikan menggunakan metode doting pada media agar dan diinkubasi selama 24 jam, untuk mengetahui aktivitas proteolitik terlihat adanya zona bening.

Uji kuantitatif sesuai dengan prosedur (Bairagi et al., 2002) dalam Setyati dan Subagiyo (2012), yaitu dengan metode divusi agar. Isolat hasil pemurnian pada media miring diambil sebanyak 1 ose dan diinokulasikan ke dalam media Zobell cair lalu diinkubasi selama 24 jam. Hasil inkubasi tersebut dilakukan pengambilan sebanyak $5 \mu$ untuk diteteskan di atas paper disk pada media agar yang diperkaya dengan skim milk (1\%). Selanjutnya di inkubasi selama 24 jam pada suhu ruang. Selanjutnya dilakukan pengukuran diameter koloni bakteri dan zona yang terdegradasi (zona bening). Berdasarkan data diameter koloni dan zona bening dapat ditentukan nilai ratio aktivitas protease, sebagai berikut :

$$
\text { Rasio } \mathrm{AP}=\frac{\mathrm{dt}}{\mathrm{d} 0}
$$

Keterangan :

$\mathrm{AP}=$ Aktivitas protease

$\mathrm{dt}=$ Diameter total zona hidrolisis (zona bening)

d0 = Diameter koloni bakteri

\section{Kultur Bakteri dalam Uji Pertumbuhan.}

Uji pertumbuhan bakteri proteolitik berasal dari isolat yang memiliki kemampuan mendegradasi protein, sehingga dilakukan pengamatan aktivitas pertumbuhan. Pengamatan aktivitas pertumbuhan menggunakan medium Zobell cair. Medium diinokulasi dengan starter $5 \mathrm{ml}$ dengan dituangkan pada media zobel cair sebanyak $300 \mathrm{ml}$. Pengamatan dilakukan jam ke 2, 4, 6, 12, 18, 24, 30, 36, 42 dan 48. Disetiap pengamatan dilakukan pengambilan data OD metode spektrofotometer (Annamalai et al., 2011).

\section{Pengukuran Kepadatan dan Berat Kering Bakteri.}

Mengukur kepadatan bakteri dengan mengambil 10 $\mathrm{ml}$ dalam valcon kemudian di sentrifuge dengan kecepatan $1.500 \mathrm{rpm}$ selama 10 menit. Hasil sentrifugasi di dapat super natan dan pelet. Pelet yang terbentuk di larutkan ke dalam PBS dan dihomogenkan. Larutan pelet di masukkan ke dalam cuvet $4 \mathrm{ml}$ dan di lakukan spektrofotometer pada panjang gelombang $600 \mathrm{~nm}$, sebagai blanko menggunakan $4 \mathrm{ml}$ PBS. Nilai absorbansi bakteri hasil spektrofotometer dilakukan konversi menjadi satuan sel / ml dengan menggunakan persamaan Mc Farland yang telah dibuat yaitu $\mathrm{y}=0,038^{*} \mathrm{x}+0,021 ; \mathrm{R} 2=0,992$. Nilai sel $/ \mathrm{ml}$ digunakan untuk menentukan nilai jumlah generasi, waktu generasi dan lajupertumbuhan bakteri, sebagai berikut :

$$
\begin{aligned}
\sum G=\frac{(\log C 1-\log C 0)}{0,301} & T g=\frac{\Delta T}{\sum G} \\
\mu & =\frac{(\ln \mathrm{C} 1-\ln \mathrm{C} 0)}{\Delta \mathrm{T}}
\end{aligned}
$$

Keterangan :

$$
\begin{array}{ll}
\sum \mathrm{G} & =\text { Jumlah generasi } \\
\mathrm{C} 1 & =\text { Jumlah sel tertinggi }(\mathrm{sel} / \mathrm{ml}) \\
\mathrm{C} 0 & =\text { Jumlah sel awal penelitian }(\mathrm{sel} / \mathrm{ml}) \\
\mathrm{Tg} & =\text { Waktu generasi }(\text { jam }) \\
\Delta \mathrm{T} & =\text { Waktu kultur }(\text { jam }) \\
\mu & =\text { Laju pertumbuhan }\left(\text { jam }^{-1}\right)
\end{array}
$$

Sampel larutan pelet dilakukan pemekatan dengan sentrifugasi $1500 \mathrm{rpm}$ selama 10 menit. Pelet dipindahkan ke cawan alumunium untuk dilakukan pengeringan pada suhu 400C hingga kering dan selanjutnya dilakukan penimbangan (Yuliana, 2008). Hasil penimbangan dilakukan penghitungan berat kering biomassa sel, sebagai berikut :

$$
\mathrm{Wk}=\mathrm{Wt}-\mathrm{W} 0
$$


Keterangan :

$\mathrm{Wk}=$ Berat kering biomassa $10 \mathrm{ml}$ kultur $(\mathrm{gram} / 10 \mathrm{ml})$

$\mathrm{Wt}=$ Berat total setelah pengeringan (gram)

$\mathrm{W} 0=$ Berat wadah (gram)

\section{HASIL DAN PEMBAHASAN}

Penelitian ini telah berhasil melakukan isolasi bakteri dari sedimen ekosistem mangrove Rhizophora mucronata Telukawur - Jepara. Berdasarkan hasil isolasi dengan media agar didapatkan nilai TPC ditiap tingkat pengenceran berbeda secara nyata $(p<0,05)$. Semakin tinggi tingkat pengenceran maka nilai TPC semakin rendah (gambar 1). Secara berurutan dari nilai tertinggi adalah pengenceran 100 sebesar $1762 \mathrm{cfu} / \mathrm{ml}, 1083 \times 101 \mathrm{cfu} / \mathrm{ml}, 829 \times 102 \mathrm{cfu} / \mathrm{ml}$, $282 \times 103 \mathrm{cfu} / \mathrm{ml}, 74 \times 104 \mathrm{cfu} / \mathrm{ml}$ dan $19 \times 105 \mathrm{cfu} / \mathrm{ml}$. Berdasarkan data nilai TPC maka dapat diketahui kelimpahan bakteri sedimen sebesar 282 x $103 \mathrm{cfu} / \mathrm{ml}$. Menurut Bashan and Gina. (2002) komunitas bakteri di ekosistem mangrove, menunjukkan bahwa jumlah bakteri yang hidup bebas berkisar antara 0.18 x 106 sampai $1,95 \mathrm{x}$ $106 \mathrm{cfu} / \mathrm{ml}$.

Hasil isolasi bakteri selanjutnya dilakukan purifikasi berdasarka morfologi koloni yang berbeda. Hasil purifikasi berhasil didapatkan sebanyak 47 isolat bakteri. Salanjutnya dilakukan uji aktivitas proteolitik kualitatif dengan metode doting. Berdasarhan hasil uji proteolitik kualitatif (gambar 2) maka didapatkan sebanyak $11 \%$ (5 isolat) aktif proteolitik, sedangkan $89 \%$ (42 isolat) tidak memiliki aktivitas proteolitik. Diduga kelima isolat yang aktif tersebut adalah dari genus Bacillus spp. Engelhard et al, (2001) mengisolasi 38 bakteri mangrove dari sedimen di Andaman Selatan. Isolat terbanyak terdiri atas bakteri yang memiliki sifat morfologi dan biokimia sebagai berikut: Gram positif $(76,3 \%)$, motil (87\%), fermentatif $(82,1 \%)$, pigmen (31\%). Isolat yang paling banyak ditemukan adalah Bacillus spp (50\%).

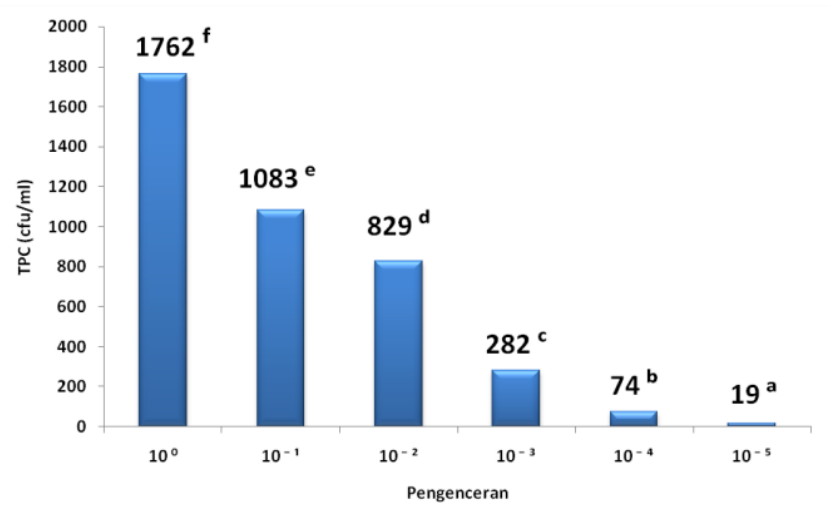

Gambar 1. Nilai TCP bakteri hasil isolasi dari sedimen ekosistem mangrove Telukawur.

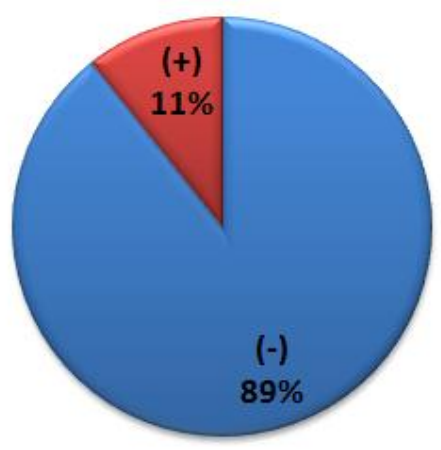

Gambar 2. Persentasi isolat bakteri yang memiliki aktivitas proteolitik.

Berdasarkan hasil proteolitik kualitatif didapatkan 5 isolat yaitu TA.R.14; 16; 22; 31 dan 39. Masing - masing isolat tersebut dilakukan ui aktivitas proteolitik kuantitatif dengan metode divusi agar. Hasil uji aktivitas proteolitik metode divusi (gambar 3) menunjukkan bahwa kelima isolat memiliki nilai ratio proteolitik yang berbeda secara signifikan $(\mathrm{p}<0,05)$. Isolat TA.R.14 memiliki nilai ratio proteolitik terendah yaitu $1,27 \mathrm{a}$, isolat TA.R 22 dan 31 memiliki nilai ratio yang tidak berbeda nyata $(\mathrm{p}>0,05)$ yaitu $1,54 \mathrm{~b}$ dan $1,69 \mathrm{bc}$. Isolat dengan nilai ratio tertinggi adalah TA.R.16 yaitu sebesar 1,96d ( $<<0,05)$. Aktivitas proteolitik ditandai dengan terbentuknya zona bening di sekitar paper disk di media skim milk. Zona bening tersebut merupakan zona hidrolisis protein skim oleh enzim ekstraseluler protease. Menurut Dias et al, (2009), enzim proteolitik yang mampu menghidrolisis protein menjadi senyawa yang lebih sederhana diantaranya menjadi oligopeptida, peptida rantai pendek dan asam amino.

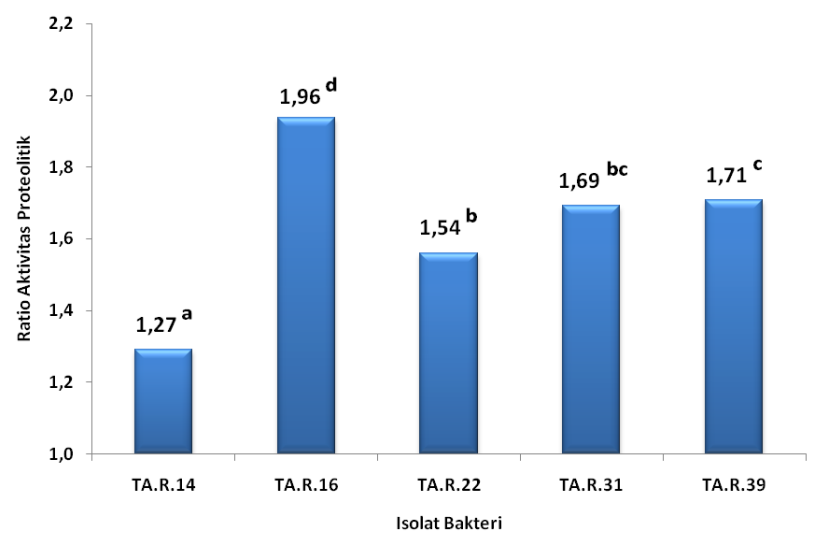

Gambar 3. Ratio aktivitas proteolitik ke-5 isolat yang aktif. Isolat TA.R.16 merupakan isolat dengan aktivitas protease tertinggi. Selanjutnya isolat tersebut dilakukan uji kinetika pertumbuhan didalam media cair dengan sistem alat fermentor. Berdasarkan gambar 4 menunjukkan bahwa terdapat kesamaan pola antara data absorbansi dengan pola data berat kering. 


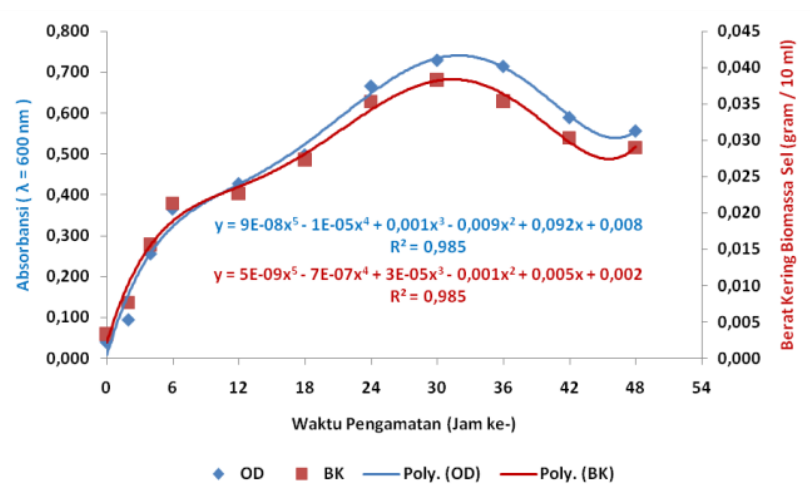

Gambar 4. Pertumbuhan bakteri pada parameter nilai absorbansi dan berat kering.

Pengamatan jam ke 0 memiliki nilai absorbansi 0,040 ; berat kering 0,03 gram $/ 10 \mathrm{ml}$ selanjutnya mengalami kenaikan sampai dengan jam ke 30. Puncak tertinggi pada inkubasi jam ke 30 dengan nilai absorbansi sebesar 0,730 dan berat kering 0,038 gram $/ 10 \mathrm{ml}$. Selanjutnya jam ke 36 sampai akhir penelitian jam ke 48 mengalami penurunan yaitu dari nilai absorbansi 0,035 dan berat kering 0,035 gram $/ 10 \mathrm{ml}$ menjadi absorbansi 0,029 dan berat kering $0,029 \mathrm{gram} / 10 \mathrm{ml}$.

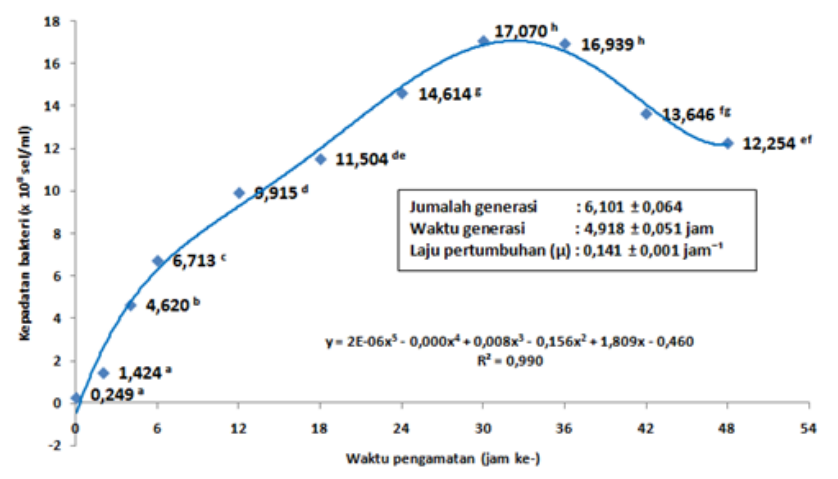

Gambar 5. Pertumbuhan bakteri pada parameter kepadatan bakteri dan laju pertumbuhan.

Berdasarkan data absorbansi tersebut selanjutnya di konversi ke satuan sel/ml dengan menggunakan persamaan Mc farland. Pertumbuhan bakteri (x $108 \mathrm{sel} / \mathrm{ml}$ ) ditunjukkan pada gambar 5. Berdasarkan gambar 5 menunjukkan bahwa pertumbuhan bakteri tidak menunjukkan adanya fase lag / fase penyesuaian hal ini diduga karena terdapat kesamaan media dan lingkungan hidup antara stater dengan media fermentor, sehingga bakteri tidak memerlukan penyesuaian. Fase penyesuaian (fase lag) terjadi jika mikroba dipindahkan ke dalam suatu media, mula-mula akan mengalami fase adaptasi untuk menyesuaikan diri dengan kondisi lingkungan di sekitarnya (Mangunwidjaja dan Suryani, 1994). Panjang atau pendeknya fase adaptasi sangat ditentukan oleh jumlah sel yang diinokulasikan, kondisi fisiologis dan morfologis yang sesuai serta media kultivasi yang dibutuhkan (Middelbeek et al., 1992). Apabila penyegaran inokulum telah sering dilakukan maka fase adaptasi dapat saja tidak diperlukan bakteri untuk menyesuaikan diri dengan lingkungannya. Middelbeek et al., (1992) menyatakan bahwa jika media dan lingkungan pertumbuhan sama seperti media dan lingkungan sebelumnya, mungkin tidak diperlukan waktu adaptasi.

Pada pengamatan jam ke 0 memiliki kepadatan bakteri $0,249 \times 108 \mathrm{sel} / \mathrm{ml}$ selanjutnya mengalami kenaikan secara signifikan $(\mathrm{p}<0,05)$ sampai pengamatan jam ke 30 . Kenaikan pertumbuhan secara signifikan ini disebut dengan fase eksponensial atau fase log. Pada fase logaritmik mikroba membelah dengan cepat dan konstan dan pada fase ini kecepatan pertumbuhan sangat dipengaruhi oleh media tempat tumbuhnya seperti $\mathrm{pH}$ dan kandungan nutrien, juga kondisi lingkungan termasuk suhu dan kelembaban udara (Middelbeek et al.,1992). Periode ini adalah keadaan pertumbuhan yang seimbang atau mantap dengan laju pertumbuhan spesifik $(\mu)$ konstan, komposisi selular tetap, sedangkan komposisi kimiawi media biakan berubah akibat terjadinya sintesis produk dan penggunaan substrat (Judoamidjojo, 1990; Mangunwidjaja dan Suryani, 1994).

Kepadatan tertinggi terjadi pada pengamatan jam ke 30 yaitu sebesar 17,070 x $108 \mathrm{sel} / \mathrm{ml}$. Selanjutnya terbentuk fase stasioner sampai pengamatan jam ke 36 hal ini ditandai nilai kepadatan bakteri yang tidak berbeda signifikan 16,939 x $108 \mathrm{sel} / \mathrm{ml}$. Pada fase ini jumlah populasi sel tetap karena jumlah sel yang tumbuh sama dengan jumlah sel yang mati. (Mangunwidjaja dan Suryani, 1994) menyatakan bahwa ukuran sel pada fase stasioner menjadi lebih kecil-kecil karena sel tetap membelah meskipun zat-zat nutrisi sudah habis.

Dari pengamatan jam ke 36 telah mengalami penurunan nilai kepadatan hingga akhir penelitian yaitu jam ke 48 sebesar 12,254 x 108 sel/ml. Penurunan kepadatan sel secara signifikan $(\mathrm{p}<0,05)$ seperti ini disebut dengan fase kematian. Pada fase ini laju pertumbuhan akhirnya menurun yang biasanya disebabkan karena kekurangan faktor pertumbuhan seperti vitamin dan unsur mineral (Gaman dan Sherrington, 1992). Berhentinya pertumbuhan juga dapat disebabkan oleh berkurangnya beberapa nutrien esensial dalam media atau karena terjadinya akumulasi autotoksin dalam media atau kombinasi dari keduanya.

Berdasarkan data kepadatan sel bakteri maka dapat ditentukan nilai laju pertumbuhan, jumlah generasi dan waktu generasi. Isolat TA.R.16 memiliki laju pertumbuhan sebesar 0,141 jam-1. Dari awal pengamatan sampai dengan titik optimal isolat TA.R.16 mengalami generasi sebanyak 6,101 dengan waktu generasi sebesar 4,918 jam. Besar kecilnya laju pertumbuhan berkaitan dengan jenis bakteri dan kondisi nutrisi pada media. Apabila dihubungkan dengan model monod (Vogel dan Todaro, 1996) dalam kondisi konsentrasi substrat rendah, penambahan konsentrasi substrat akan menambah laju pertumbuhan spesifik, namun pada batas tertentu konsentrasi substrat tidak berpengaruh nyata terhadap laju pertumbuhan 
spesifik, sehingga laju pertumbuhan sel konstan, dan dapat terjadi penghambatan oleh substrat itu sendiri.

\section{SIMPULAN DAN SARAN}

Berdasarkan data aktivitas proteolitik maka dapat diketahui bahwa isolat TA.R.16 yang paling potensial untuk dijadikan sebagai kandidat konsursium water probiotik karena memiliki nilai ratio protease tertinggi serta memiliki laju pertumbuhan dan kepadatan sel yang tinggi.

\section{UCAPAN TERIMAKASIH}

Penulis mengucapkan terimakasih kepada LPPM UNISNU Jepara yang telah mensuport dalam biaya penelitian dalam program penelitian reguler universitas. Selain itu juga, mengucapkan terimakasih kepada Ka Prodi Budidaya Perairan UNISNU Jepara atas kesempatan yang diberikan kepada penulis untuk dapat mengerjakan penelitian ini.

\section{DAFTAR PUSTAKA}

Annamalai, N., Kumar, A., Savanakumar, A., Vijajlakshmi, A., and Balasubramanian, T., 2011, "Characterization of Protease from Algaligens faecalis and Its antibacterial Activity on Fish Patogens", J. Environ. Biol, 32, hal. 781-786.

Bairagi, A., Ghosh, K., Kumarsen, S., Ray, A.K., 2002, "Enzyme Producing Bacterial Flora Isolated From Fish Digestive Tracts", Aquaculture International, Vol. 10, hal. 109-121.

Bashan, Y. \& H, Gina. 2002. Plant growth-promoting bacteria: a potential tool for arid mangrove reforestation. Environ. Microbiol. CIB. 16:159166.

Dias A. C. F., F. D. Andreote, F. Dini-Andreote, P. T. Lacava, A. L. B. Sa, I. S. Melo, J. L. Azevedo, W. L. Arau' jo, 2009, Diversity and biotechnological potential of culturable bacteria from Brazilian mangrove sediment World J Microbiol Biotechnol 25:1305-1311

Engelhard, M.A., K. Daly, R.P.J. Swannell \& I.M. Head. 2001. Isolation and characterization of a novel hydrocarbon-degrading, Gram-positive bacterium, isolated from intertidal beach sediment, and descriptionof Planococcus alkanoclasticus sp. nov. J. Appl. Microbiol.90:237-247.

Gaman,P.M. and Sherington,B. 1992. Pengantar Ilmu Pangan Nutrisi dan Mikrobiologi.Edisi Kedua. Yogyakarta: Gadjahmada University Press.

Hsu .S and Chen . 2007. The immune response of white shrimp Penaeus vannamei and its susceptibility to Vibrio alginolyticus under sulfide stress. Aquaculture. Vol. 271. pp: 61-69.

Irianto K. 2006. Mikrobiologi: Menguak Dunia Mikroorganisme Jilid 1. Bandung: Yrama Widya.

Judoamidjojo, M., Abdul A.D., dan Endang, G.S. 1990. Teknologi Fermentasi. Rajawali Press. Jakarta.
Mangunwidjaja, D. Dan A. Suryani. 1994. Tekologi Bioproses. Penerbit Swadaya. Jakarta. $394 \mathrm{hlm}$.

Middlebeek, E.J., R.O. Jenkins and J.S. Drijver-de Haas. 1992. Growth in batch culture. In Vitro Cultivation of Micro-organisms. Biotechnology by Open Learning.

Setyati, W.A., dan Subagiyo. 2012. Isolasi dan Seleksi Bakteri Penghasil Enzim Ekstraseluler (proteolitik, amilolitik, lipolitik dan selulolitik) yang Berasal dari Sedimen Kawasan Mangrove. Jurnal Ilmu Kelautan. September 2012. Vol. 17 (3) 164-168. ISSN 08537291. 1-6 hlm.

Setyati, W.A., Erni, M., Triyanto, Subagiyo, and Zainuddin, M., 2014, "Selection Identification and Optimization of the Growth Water Probiotic Consortium of Mangrove Ecosystems as Bioremediation and Biocontrol in Shrimp Ponds", J. Pengolahan Hasil Perikanan Indonesia, Vol.17, No.3, hal. 242-252.

Taslihan, A., Astuti, S.M, Nur, E.M dan Zari'ah. 2001. Petunjuk Praktikum Cara Isolasi Bakteri dari Air,Udang dan Ikan. BBPAP, Jepara, $33 \mathrm{hlm}$.

Vogel, H.C. dan Torado, C.L. 1996. Fermentation and Biochemical Engineering Handbook; Principles, Process Design and Equipment Noyes Publication, New Jersey.

Waluyo, L. 2007. Mikrobiologi Umum, Edisi Revisi. UMM Press, Malang, 372hlm.

Waluyo, L., 2008, Teknik Metode Dasar Mikrobiologi, Universitas Muhamadiyah Malang Press, Malang.

Yuliana, N., 2008, "Kinetika Pertumbuhan Bakteri Asam Laktat Isolat T5 yang Berasal dari Tempoyak", J. Teknologi Industri dan Hasil Pertanian, Vol. 13, No.2, hal. 108-116. 